\title{
Pengaruh Atribut Produk Tabungan Faedah Terhadap Minat Menabung Nasabah
}

\author{
Fathnun Ashar ${ }^{1 *}$,Siti Aisyah ${ }^{2}$, Muhammad Syafaat ${ }^{3}$ \\ ${ }^{1}$ Jurusan Perbankan Syariah, Fakultas Ekonomi dan Bisnis Islam, IAIN Palu \\ 2 Jurusan Perbankan Syariah, Fakultas Ekonomi dan Bisnis Islam, IAIN Palu, \\ ${ }^{3}$ Jurusan Ekonomi Syariah, Fakultas Ekonomi dan Bisnis Islam, IAIN Palu
}

ABSTRAK

Penelitian ini ditujukan untuk mengetahui pengaruh atribut produk tabungan Faedah terhadap minat menabung Nasabah pada BRI Syariah Palu. Penelitian menggunakan metode kuantitatif. Sampel penelitian ini berjumlah 99 orang. Sampel dipilih secara acak pada bank BRI Syariah Palu. Data diolah dengan menggunakan SPSS. Hasil penelitian ini menunjukkan hasil Analisa data dapat diketahui bahwa variabel tentang atribut produk memiliki nilai t-hitung sebesar 7,129 > nilai $t$-tabel sebesar 1,988, serta tingkat signifikannya lebih besar dari taraf kepercayaan sebesar $10 \%$ yaitu $0,000<0,05$. Dengan demikian nilai tersebut menunjukan bahwa variabel atribut produk (X) memberikan pengaruh yang signifikan terhadap variabel minat menabung (Y). Maka dari pembahasan ini menunjukan bahwa variabel atribut produk mempengaruhi minat menabung nasabah di BRI Syariah KC Palu Wolter Monginsidi. Hasil penelitan ini memberi kontribusi baik secara akademik maupun praktis bagi pihak lembaga keuangan.
INFORMASI

ARTIKEL

\section{Katakunci:}

Atribut produk, Tabungan Faedah, Minat Menabung, Nasabah, BRI Syariah 


\section{PENDAHULUAN}

Kemajuan teknologi saat ini telah memudahkan seseorang untuk mengembangkan usahanya, demikian juga dengan perkembangan industri perbankan yang tidak jauh berbeda tingkat perkembangannya dengan industri-industri lainnya. Dengan menyesuaikan zaman dan adanya kebutuhan serta masukan dari masyarakat luas, perbankan yang ada saat ini banyak mengalami perkembangan. Perkembangan ini diwujudkan dalam bentuk yang bervariasi baik dari segi inovasi produk, prinsip, sistem operasionalnya serta pergeseran paradigma sampai pada pengkonversian diri. ${ }^{1}$

Dari pergeseran dan perkembangan yang ada tersebut, dalam kurun waktu terakhir, muncul lembaga-lembaga keuangan berbasis syari'ah yang mana sebagai salah satu tonggak penting dalam pengembangan ekonomi syari'ah di Indonesia, di mana perkembangannya mengalami peningkatan yang cukup menggembirakan. Perkembangan sistem keuangan syari'ah semakin kuat dengan ditetapkannya dasardasar hukum operasional melalui UU No. 7 tahun 1992 tentang perbankan yang telah dirubah dalam UU No. 10 tahun 1998, UU

${ }^{1}$ Kasmir, Pemasaran Bank (Ed. Revisi, Cet. III, Jakarta: Kencana Prenada Media Group, 2008),1.
No.23 tahun 1999, UU No.9 tahun 2004 tentang Bank Indonesia, dan UU No. 21 tahun 2008 tentang bank syariah. Tentu dukungan regulasi dari pemerintah ini memberikan peluang bagi beroperasinya bank dengan sistem syariah.

Dalam kata pengantar buku "JejakJejak Ekonomi Syariah" oleh M. Luthfi Hamidi, Kepala Biro Perbankan Syari'ah Bank Indonesia mengatakan : Fenomena meningkatnya kebutuhan masyarakat terhadap keberadaan sistem perbankan sesuai dengan prinsip syari'ah mendapat respon positif dari pemerintah yang antara lain melalui dikeluarkannya UU No. 7 tahun 1992 tentang perbankan yang menetapkan bahwa perbankan di Indonesia menganut dual banking system, yaitu perbankan konvensional dan perbankan syari'ah. ${ }^{2}$

Pada awal pendirian Bank Muamalat Indonesia, keberadaan bank syariah ini belum mendapat perhatian yang optimal dalam tatanan industri perbankan nasional. ${ }^{3}$ Manajemen bank syariah tidak banyak berbeda dengan manajemen bank pada umumnya (bank konvensional). Namun

${ }^{2}$ M. Luthfi Hamidi, Jejak Jejak Ekonomi Sya riah (Cet. I, Jakarta: Senayan Abadi Publishing, 2003) , 1 .

${ }^{3}$ Muhammad Syafi'i Antonio, Bank Syariah dari Teori ke Praktik (Cet. I, Jakarta: Gema Insani, 2001),26. 
dengan adanya landasan syariah serta sesuai dengan pemerintah yang menyangkut bank syariah antara lain UU No. 10 tahun 1998 sebagai revisi UU No. 7 tahun 1992, tentu saja baik organisasi maupun sistem operasional bank syariah terdapat perbedaan dengan bank pada umumnya, terutama adanya dewan pengawas syariah dalam struktur organisasi dan sistem bagi hasil. ${ }^{4}$

Didirikannya bank syariah dilatar belakangi oleh keinginan umat islam untuk menghindari riba dalam kegiatan muamalahnya, memperoleh kesejahteraan lahir batin melalui kegiatan muamalah yang sesuai dengan perintah agamanya, sebagai alternatif lain dalam menikmati jasa-jasa perbankan yang dirasakannya lebih sesuai, yaitu bank yang berusaha sebisa mungkin untuk beroperasi berlandaskan kepada hukum-hukum islam. ${ }^{5}$

Keberhasilan sistem keuangan syariah hingga sekarang ini tidak semata-mata atas adanya dukungan regulasi pemerintah, namun juga didukung oleh produk yang diberikan oleh lembaga tersebut. Lembaga keuangan syariah yang dalam hal ini adalah

\section{${ }^{4}$ Muhammad, Sistem dan Prosedur Operasional Bank Syariah (Ed. Revisi, Yogyakarta:}

UII Press, 2008), 1.

${ }^{5}$ Edi Wibowo dan Untung Hendy, Mengapa Memilih Bank Syariah? (Cet. I, Bogor: Ghalia Indonesia, 2005), 1. perbankan syariah secara umum, dianggap oleh sebagian orang sebagai alternatif bagi masyarakat yang sudah lama mendunia yang selalu mengutamakan kekayaan pribadi berdampak pada ketidakmerataan distribusi kekayaan sehingga banyak terjadi kesengsaraan.

Produk dapat dirumuskan sebagai sekumpulan atribut berwujud ataupun tidak, yang di dalamnya tercakup warna, harga, kemasan, serta pelayanan yang mungkin diterima oleh pembeli, sebagai suatu yang dapat memuaskan kebutuhannya. Atribut produk sangatlah penting untuk dijadikan dasar oleh konsumen dalam pembelian sebuah produk, sebab untuk melakukan pembelian konsumen akan bereaksi terhadap produk dengan segala atribut yang melekat di dalamnya. ${ }^{6}$ Atribut produk inilah yang merupakan penilaian menyeluruh atas keunggulan suatu perusahaan. Kualitas atribut produk mempunyai pengaruh yang cukup besar dalam menentukan minat nasabah untuk menggunakan jasa yang dalam hal ini adalah menabung.

Salah satunya yaitu Bank BRI Syari'ah yang berperan memberikan alternatif bagi masyarakat Islam khususnya dan masyarakat pada umumnya untuk melakukan kegiatan

${ }^{6}$ Daromi S dan Sri Hardjanti Santosa, Kebijakan Bauran Pemasaran (Yogyakarta: BPFE, 1992), 19. 
melalui cara yang lebih sesuai dengan ketentuan ajaran agama Islam, selain itu Bank BRI Syariah juga termasuk bank syariah terbesar ketiga di Indonesia setelah Bank Muamalat, dan BNI Syariah dengan total DPK periode Desember 2018 yaitu 36.639.181.846,-. Yang lebih menariknya lagi di milad ke 10 tahun, BRI Syariah telah meluncurkan 6 produk dalam hal ini untuk membawa BRI Syariah bertransformasi menjadi bank digital dengan tujuan untuk meningkatkan teknologi terutama di bidang digital banking. Selain itu, Bank BRI Syariah juga mempunyai produk yang unggul. Produk tersebut ialah tabungan faedah, yaitu tabungan simpanan harian untuk perorangan dengan prinsip sesuai syariat Islam dengan skema wadiah atau titipan. Selain itu, Tabungan Faedah BRI Syariah termasuk simpanan yang dijamin LPS sehingga menjadi tabungan yang utama, dan tabungan yang paling banyak digunakan

Berdasarkan penelitian sebelumnya ditemukan bahwa tabungan Faedah menduduki posisi pertama dalam produk tabungan dengan presentase jumlah nasabahnya $50 \%$, presentase jumlah rekeningnya $50 \%$ dan presentase total saldonya $41 \%$. Dengan demikian, penulis tertarik untuk mengkaji lebih dalam mengenai pengaruh atribut produk tabungan faedah terhadap minat menabung nasabah,

\section{TINJAUAN PUSTAKA}

\subsection{Atribut Produk}

Produk dalam kamus besar bahasa Indonesia adalah barang atau jasa yang dibuat dan ditambah gunanya atau nilainya dalam proses produksi dan menjadi hasil akhir dari proses produksi itu. ${ }^{7}$

Produk adalah segala sesuatu yang dapat ditawarkan untuk memuaskan suatu kebutuhan dan keinginan. Pelanggan memuaskan kebutuhan dan keinginannya lewat produk. Produk dapat dibedakan menjadi tiga jenis yaitu barang fisik, jasa dan gagasan. ${ }^{8}$ Produk juga mempunyai arti kata barang-barang fisik maupun jasa yang dapat memuaskan kebutuhan konsumen. ${ }^{9}$

\section{a. Pengertian Atribut Produk}

Atribut produk adalah suatu komponen yang merupakan sifat-sifat produk yang menjamin agar produk tersebut dapat memenuhi kebutuhan dan keinginan yang ditetapkan oleh pembeli. ${ }^{10}$ Menurut Fandy Tjiptono, atribut produk adalah unsur-unsur

\footnotetext{
${ }^{7}$ Dendy Sugono dkk, Kamus Bahasa Indones ia (Ed. IV Jakarta: Pusat Bahasa, 2008),1215

${ }^{8}$ Veitzhal Rivai, Islamic Marketing (Jakarta: Gramedia Pustaka Utama, 2012),12.

${ }^{9}$ Jeff Madura, Pengantar Bisnis Buku 1 ( Ed. IV, Jakarta: Salemba Empat, 2001),393.

${ }^{10}$ Kotler, Manajemen Pemasaran (Ed. XII, Jakarta: Erlangga, 1997),72.
} 
produk yang dipandang oleh konsumen dan dijadikan dasar pengambilan keputusan pembelian. ${ }^{11}$

Dengan adanya atribut yang melekat pada suatu produk yang digunakan konsumen untuk menilai dan mengukur kesesuaian karakteristik produk dengan kebutuhan dan keinginan. Bagi perusahaan dengan mengetahui atribut-atribut apa saja yang bisa mempengaruhi keputusan pembelian maka dapat ditentukan strategi untuk mengembangkan dan menyempurnakan produk agar lebih memuaskan konsumen. Suatu produk harus memiliki atribut yang mendukungnya, contohnya adalah harga yang berfungsi sebagai harga beli yang berlaku bagi konsumen.

Di samping itu perlu dilakukan beberapa inovasi terhadap atribut produk yang dihasilkan seperti peningkatan kualitas suatu produk. Hal ini perlu dilakukan untuk memperluas pangsa pasar dan agar perusahaan bisa tetap mempertahankan konsumennya.

\section{b. Unsur-unsur dalam Atribut Produk}

1) Tidak mengandung unsur riba

Riba merupakan penambahan pendapatan secara tidak sah (batil) antara

\footnotetext{
${ }^{11}$ Fandy Tjiptono, Strategi Pemasaran (Cet. I, Yogyakarta: Andi, 1997), 103.
}

lain dalam transaksi pertukaran barang sejenis yang tidak sama kualitas, kuantitas, dan waktu penyerahan, atau dalam transaksi pinjam meminjam yang mempersyaratkan nasabah penerima fasilitas mengembalikan dana yang diterima melebihi pokok pinjaman karena berjalannya waktu.

2) Hasil investasi dibagi menurut sistem bagi hasil

Suatu sistem yang meliputi tata cara pembagian hasil usaha antara penyedia dana dengan pengelola dana. Pembagian hasil usaha ini dapat terjadi antara bank dengan penyimpan dana, maupun antara bank dengan nasabah penerima dana.

3) Menghindari unsur gharar (tidak jelas) dan judi (maisir)

Maisir merupakan transaksi yang digantungkan kepada suatu keadaan yang tidak pasti dan bersifat untung-untungan.

4) Melakukan investasi yang halal

Investasi hanya boleh diberikan pada usaha-usaha yang tidak diharamkan dalam Islam. Usaha minuman keras misalnya tidak boleh didanai oleh Perbankan Syariah.

5) Melakukan aktivitas sesuai dengan syariah

Bank syariah melakukan kegiatan perbankan dengan menggunakan profit dan falah (mencari kemakmuran di dunia dan di akhirat). Bank syariah tidak hanya sekedar menyalurkan uang tetapi terus berupaya 
meningkatkan kembalian atau return of investment sehingga lebih menarik dan lebih memberi kepercayaan bagi pemilik dana.

Atribut-atribut produk khas tersebut yang menjadi alasan pokok para nasabah yang beragama Islam menggunakan bank syariah sekaligus menjadi indikator penilaian bagi nasabah. Jika atribut-atribut khas tersebut dapat dirasakan manfaatnya oleh nasabah maka nasabah akan memberikan penilaian yang positif atas atribut produk Islam tersebut. $^{12}$

\subsection{Minat Menabung}

\section{a. Pengertian Minat}

Minat dalam kamus besar bahasa Indonesia diartikan sebagai sebuah kecenderungan hati yang tinggi terhadap sesuatu keinginan. ${ }^{13}$ Minat merupakan kecenderungan seseorang untuk menentukan pilihan aktivitas. Pengaruh kondisi-kondisi individual dapat merubah minat seseorang.

\footnotetext{
${ }^{12}$ Iqbal dalam Rahman El-Yunusi, "Pengaruh Atribut Islam, Komitmen Agama, Kualitas Jasa dan kepercayaan terhadap Kepuasan dan Loyalitas Nasabah Bank Syariah (pada Bank Muamalat Kota Ssemarang)", Jurnal Annual Converence On Islamic Studies ke 9 tahun, Dosen Prodi Ekonomi Islam Fakultas Syariah IAIN Walisongo Semarang, 2009),2.

${ }^{13}$ Anton M. Moeliono dkk, Kamus Besar Bahasa Indonesia (Jakarta: Balai Pustaka, 1999),225.
}

Sehingga dapat dikatakan minat sifatnya tidak stabil. ${ }^{14}$

Secara etimologi pengertian minat adalah perhatian, kesukaan (kecenderungan hati) kepada sesuatu keinginan. ${ }^{15}$ Sedangkan menurut istilah ialah suatu perangkat mental yang terdiri dari suatu campuran dari perasaan, harapan, pendirian, prasangka atau kecenderungan lain yang mengarahkan individu kepada suatu pilihan tertentu. ${ }^{16}$

Minat merupakan motivasi yang mendorong orang untuk melakukan apa yang mereka inginkan bila mereka bebas memilih. Setiap minat akan memuaskan suatu kebutuhan. Dalam melakukan fungsinya kehendak itu berhubungan erat dengan pikiran dan perasaan. Pikiran mempunyai kecenderungan bergerak dalam sektor rasional analisis, sedang perasaan yang bersifat halus/tajam lebih mendambakan kebutuhan. Sedangkan akal berfungsi sebagai pengingat fikiran dan perasaan itu dalam koordinasi yang harmonis, agar

\footnotetext{
${ }^{14}$ Muhaimin, Korelasi Minat Belajar Pendidikan Jasmani terhadap hasil Belajar Pendidikan Jasmani (Semarang: IKIP, 1994),4.

${ }^{15}$ WJS. Poerwadarminta, Kamus Umum Bahasa Indonesia (Jakarta: Balai Pustaka, 1982),650.

${ }^{16}$ Andi Mappiare, Psikologi Remaja
} (Surabaya: Usaha Nasional, 1997),62. 
kehendak bisa diatur dengan sebaikbaiknya. ${ }^{17}$

Ada beberapa tahapan minat dalam menabung antara lain :

- Informasi yang jelas sebelum menjadi nasabah

$c$

- Pertimbangan yang matang sebelum menjadi nasabah

- Keputusan menjadi nasabah

Dengan demikian maka dapat dikatakan bahwa minat adalah dorongan kuat bagi seseorang untuk melakukan segala sesuatu dalam mewujudkan pencapaian tujuan dan cita-cita yang menjadi keinginanya. Selain itu minat dapat timbul karena adanya faktor eksternal dan juga adanya faktor internal. Minat yang besar terhadap suatu hal merupakan modal yang besar untuk membangkitkan semangat untuk melakukan tindakan yang diminati dalam hal ini minat menabung.

\section{b. Faktor-faktor yang Mempengaruhi Timbulnya Minat}

Menurut Crow dalam bukunya Abdul Rahman Saleh berpendapat ada tiga faktor yang mempengaruhi timbulnya minat, yaitu:

1) Dorongan dari dalam diri individu, misal dorongan makan, rasa ingin tahu dan seks.

${ }^{17}$ Sukanto, Nafsiologi (Jakarta: Integritas Press, 1985), 120.
2) Motif sosial, dapat menjadi faktor yang membangkitkan minat untuk melakukan suatu aktivitas tertentu.

3) Faktor emosional, minat mempunyai hubungan yang erat dengan emosi. ${ }^{18}$

\section{Proses Terbentuknya Minat}

Menurut Charles yang dikutip oleh Slamet Widodo dideskripsikan sebagai berikut:

Pada awalnya sebelum terlibat di dalam suatu aktivitas, seseorang mempunyai perhatian sehingga menimbulkan keinginan untuk terlibat di dalam aktivitas. Minat kemudian mulai memberikan daya tarik yang ada atau ada pengalaman yang menyenangkan dengan hal-hal tersebut. Secara skematis proses terbentuknya minat dapat digambarkan sebagai berikut:

Gambar 1. Proses Terbentuk Minat

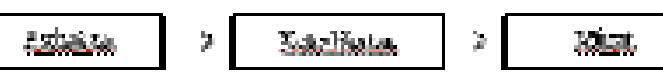

\subsection{Hipotesis}

Hipotesis berasal dari kata hypo yang berarti dibawah dan thesa yang berarti kebenaran, hipotesis dapat didefinisikan sebagai jawaban sementara yang kebenarannya masih harus diuji. Hipotesis

${ }^{18}$ Abdul Rahman Shaleh, dkk, Psikologi Suatu Pengantar Dalam Perspektif Islam (Jakarta: Kencana, 2004),270. 
juga merupakan proposisi yang akan diuji keberlakuannya atau merupakan suatu jawaban sementara atas pertanyaan penelitian. $^{19}$

Berdasarkan latar belakang dan masalah yang dikemukakan maka hipotesis yang digunakan dalam penelitian ini adalah :

Ha : Diduga bahwa atribut produk tabungan faedah berpengaruh terhadap minat menabung nasabah (studi kasus BRI Syariah KC Palu Wolter Monginsidi).

\section{METODE PENELITIAN}

Pendekatan yang digunakan dalam penulisan ini adalah pendekatan kuantitatif, karena data yang akan dianalisis dalam penelitian ini berbentuk angka dan menggunakan analisis statistic. Penelitian ini berlokasi di Jl. Wolter Monginsidi No. 133 C Kota Palu, Kecamatan Palu Selatan, Provinsi Sulawesi Tengah.

Populasi merupakan keseluruhan unsur-unsur yang memiliki satu atau beberapa ciri atau karakteristik yang sama. ${ }^{20}$ Populasi dari penelitian ini adalah nasabah

${ }^{19}$ Nanang Martono,Metode Penelitian Kuantitatif Analisis Isi dan Analisis Data Sekunder (Edisi revisi II, Cet V; Jakarta: PT. RajaGrafindo Persada, 2016), 67.

${ }^{20}$ Sugiyono, Metode Penelitian Pendidikan Pendekatan Kuantitatif, Kualitatif, dan $R$ dan D.(Cet. 20,Bandung: Alfabeta, 2014), 297.
BRI Syariah KC Palu sebanyak 6.741 nasabah.

Sedangkan sampel adalah bagian dari jumlah dan karakteristik yang dimiliki oleh populasi. Sedangkan teknik sampling merupakan teknik pengambilan sampel. Untuk menetukan besarnya sampel, peneliti menggunakan rumus dengan Metode Slovin. ${ }^{21}$ Berdasarkan rumus tersebut maka diperoleh sampel dalam penelitian ini sebanyak 99 nasabah BRI Syariah KC Palu yang menggunakan produk tabungan faedah dari 6.741 yang menjadi populasi.

Metode dalam pengambilan sampel adalah teknik probability sampling yaitu teknik pengambilan sampel yang memberikan peluang yang sama bagi setiap unsur (anggota) populasi untuk dipilih menjadi anggota sampel dengan cara simple random sampling dimana peneliti mengambil anggota sampel dari populasi dilakukan secara acak tanpa memperhatikan strata yang ada dalam populasi. ${ }^{22}$

Data dikumpul dengan cara membagi survey kepada sampel yang tlah dipilih.

\footnotetext{
${ }^{21}$ Muhammad, Metode Penelitian Ekonomi Islam Pendekatan Kuantitatif (Cet. I, Jakarta: Rajawali Pers, 2008), 180.

${ }^{22}$ Syofian Siregar, Statistika Deskriptif untuk Penelitian (Ed. I,Cet.I, Jakarta: PT. RajaGrafindo Persada, 2010), 145.
} 
Sedangkan hasil survey diolah dengan menggunakan SPSS ${ }^{23}$.

\section{HASIL DAN PEMBAHASAN}

\subsection{Karakteristik Responden}

Responden penelitian berjumlah 99 orang yang dipilih secara acak. Jumlah responden tersebut terdiri dari 36 orang lakilaki dan 63 orang perempuan. Karakteristik responden dapat dijelaskan pada table 1. berikut ini.

Tabel 1. Karakteristik Responden

\begin{tabular}{|c|c|c|}
\hline 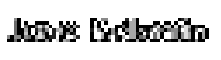 & Joxy zedbri. & 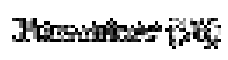 \\
\hline 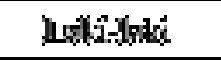 & $5 y$ & Hors \\
\hline Prezecteress. & 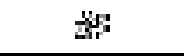 & 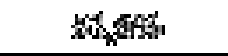 \\
\hline Xinow & ริจ & 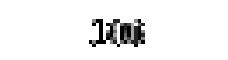 \\
\hline
\end{tabular}

\subsection{Uji Validitas dan Reliabilitas}

Dengan menggunakan instrumen yang valid dan realibel dalam pengumpulan data, maka diharapkan hasil penelitian akan menjadi valid dan realibel. Jadi instrumen valid dan realibel merupakan syarat mutlak untuk mendapatkan hasil penelitian yang valid dan realibel. Hal ini tidak berarti bahwa dengan menggunakan instrumen yang

23 Nurdin, N., Pettalongi, S. S., \& Mangasing, M. (2019, 26-27 Sept. 2019). Understanding Digital Skill Use from The Technology Continuance Theory (TCT). Paper presented at the 2019 6th International Conference on Information Technology, Computer and Electrical Engineering (ICITACEE). telah teruji validitas dan realibitasnya, otomatis hasil (data) penelitian menjadi valid dan realibel. Hal ini masih akan di pengaruhi oleh kondisi objek yang di teliti, dan kemapuan orang yang menggunakan instrumen untuk mengumpulkan data.

Instrumen yang dinyatakan valid dan realibel adalah; instrumen yang valid, berarti alat ukur yang digunakan untuk mendapatkan data (mengukur) itu valid. Valid berarti instrumen tersebut dapat digunakan untuk mengukur apa yang seharusnya diukur. Sedangkan instrumen yang realibel berarti bila digunakan untuk mengukur berkali-kali akan menghasilkan data yang sama.

a. Uji Validitas

Uji validitas yaitu mengkorelasikan masing-masing pernyataan dengan jumlah skor untuk masing-masing variabel. Syarat minimum untuk memenuhi syarat adalah apabila $\mathrm{r}=0,3$ jadi apabila korelasi antar butir dengan skor total kurang dari 0,3 maka instrumen tersebut tidak valid. ${ }^{24}$

Tabel 2. Hasil Uji Validitas

${ }^{24}$ Sugiyono, Metode Penelitian Kuantitatif, Kualitatif dan $R$ an D, (Cet.XIII, Bandung: CV. Alfabeta, 2011), 20. 


\begin{tabular}{|c|c|c|c|}
\hline 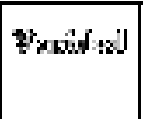 & 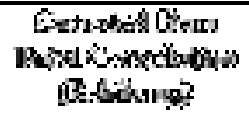 & Ee-tiritis & Kentercicuspon: \\
\hline \multicolumn{4}{|c|}{ 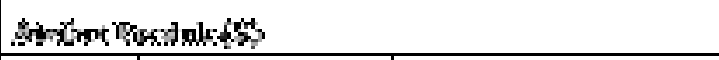 } \\
\hline 1 & $6, N \in C$ & 0,45 & 络学 \\
\hline $\mathrm{g}$ & 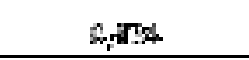 & $5 \times$ & $n: k$ su \\
\hline$\underline{D}$ & $43 \%$ & $2 x y$ & Ftix \\
\hline 1 & 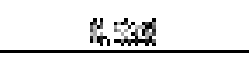 & $\hat{u}_{r} y_{y}$ & 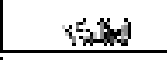 \\
\hline 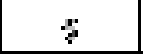 & 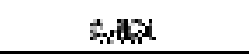 & 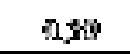 & sided \\
\hline \multicolumn{4}{|c|}{ 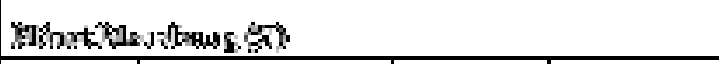 } \\
\hline il & 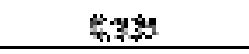 & $u_{r}^{n+4}$ & 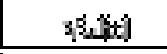 \\
\hline 3 & wats & axy & dist \\
\hline$x$ & 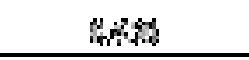 & Q & 䋆然 \\
\hline$\star$ & z,yses & $\sin 20$ & 30.40 \\
\hline 5 & mast & Driy & 许然 \\
\hline
\end{tabular}

Berdasarkan tabel 4.4 diatas hasil uji validitas, maka dapat dinyatakan bahwa semua instrumen layak ikut sertakan dalam penelitian ini, karena koefisien korelasi (rhitung) seluruh item pernyataan yang diperoleh lebih besar dari nilai r-kritis yaitu 0,30 .

b. Uji Reliabilitas

Setelah instrumen dalam penelitian ini dinyatakan valid, maka selanjutnya perlu dilakukan uji reliabilitas atau uji keandalan instrumen penelitian.

Pengujian reliabilitas dilakukan4.3 Analisis Regresi Linear Sederhana dengan internal consistensy atau derajat ketepatan jawaban. Untuk penelitian ini digunakan Statistical Packaged For social Sciences (SPSS) sebagai alternatif pengujian reliabilitas untuk mengetahui konsistensi hasil sebuah jawaban tentang tanggapan responden. Untuk melakukan pengujian reliabititas penulis menggunakan SPSS versi 21, yaitu dalam mengukur reliabilitas disini menggunakan uji statistik Cronbach Alpha $(\alpha)$, yang mana satu variabel dikatakan reliabel jika memiliki Cronbach Alpha lebih dari $0,60(>0,60){ }^{25}$

Hasil pengujian reliabilitas instrumen menggunakan alat bantu oleh statistik SPSS versi 21.0 for windows dapat diketahui dalam tabel berikut:

Tabel 3. Hasil Uji Validaitas

\begin{tabular}{|c|c|c|}
\hline$v_{\text {sat:3xa-1 }}$ & 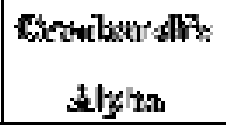 & Exidatanosto \\
\hline Atillaserpoling & 员然果 & Ruthorol \\
\hline buturatsyoxterng & 4,659 & Rutedited \\
\hline
\end{tabular}

Berdasarkan pada tabel 4.5 tersebut tampilan SPSS menunjukan bahwa nilai Cronbanch Alpha> 0,60 yang menurut kriteria sebelumnya bisa dikatakan reliabel, sehingga dapat disimpulkan sesuai item pernyataan dari variabel $\mathrm{X}$ dan $\mathrm{Y}$ dapat diuji lebih lanjut.

Penelitian ini bertujuan untuk menguji dan mengetahui besarnya pengaruh atribut produk tabungan Faedah terhadap minat menabung nasabah di BRI Syariah KC

\footnotetext{
${ }^{25} \mathrm{Ibid}, 56$.
} 
Palu. Digunakan metode analisis regresi dapat mempengaruhi minat menabung linear sederhana dengan menggunakan nasabah BRI Syariah semakin naik. program SPSS 21. Analisis tersebut dapat 1. Uji Hipotesis dilihat sebagai berikut :

Uji hipotesis dilakukan dengan Uji T.

Tabel 4. Hasil Regresi Linear Sederhana

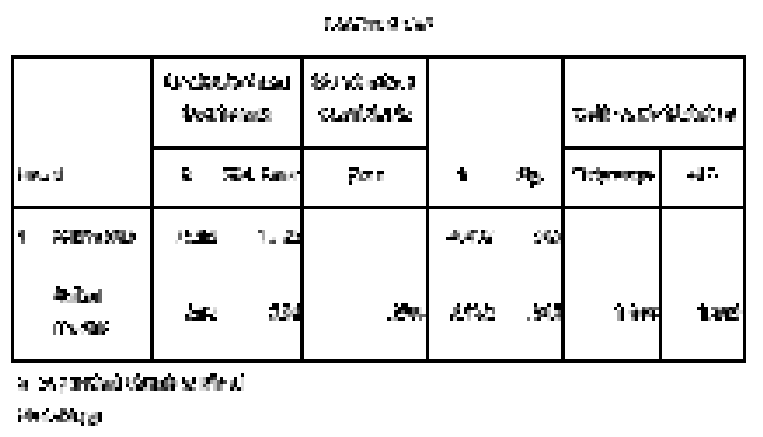

Persamaan regresi linear sederhana di atas menunjukan bahwa variabel independen atau atribut produk mempengaruhi variabel dependen, hal ini dapat dilihat dan dijelaskan bahwa nilai Sig $(0,00)<\alpha(0,05)$, maka hasil tersebut bermakna bahwa atribut produk memiliki pengaruh terhadap minat menabung.

$$
\mathrm{Y}=7,918+0,612 \mathrm{X}
$$

1) Konstanta

Adapun nilai konstanta sebesar 7,918, artinya tanpa adanya atribut produk maka minat menabung nasabah BRI Syariah memiliki persepsi positif.

2) Atribut Produk

Adapun koefisien atribut produk sebesar 0,612, yang menunjukan bahwa apabila atribut produk meningkat, maka 4.4 Uji Koefisien Determinasi Koefisien determinasi digunakan

untuk mengukur seberapa besar presentase

Uji T dilakukan untuk mengetahui pengaruh antara atribut produk terhadap minat menabung nasabah di Bank BRI Syariah KC Palu, maka dilanjutkan Uji $\mathrm{T}$ yang dapat dilihat sebagai berikut :

Berdasarkan hasil perhitungan statistik, maka dapat diketahui bahwa variabel tentang atribut produk memiliki nilai t-hitung sebesar $7,129>$ nilai $\quad t$-tabel sebesar 1,988 serta tingkat signifikannya $10 \%$ yaitu $0,000>0,05$. Dengan demikian nilai menunjukan bahwa variabel atribut produk (X) memberikan pengaruh yang signifikan terhadap variabel minat menabung (Y). Berdasarkan uji $\mathrm{T}$ tersebut, hipotesis dalam penelitian ini yang menyatakan bahwa "Pengaruh atribut produk tabungan Faedah berpengaruh secara positif dan signifikan terhadap minat menabung nasabah di Bank BRI Syariah KC Palu Wolter Monginsidi”,

\section{diterima.} lebih besar dari taraf kepercayaan sebesar 
sumbangan pengaruh variabel bebas secara parsial terhadap variabel terikat. Adapun koefisien determinasi dapat dilihat dalam4.5 Pembahasan tabel berikut :

Tabel 5. Koefisien Determinasi

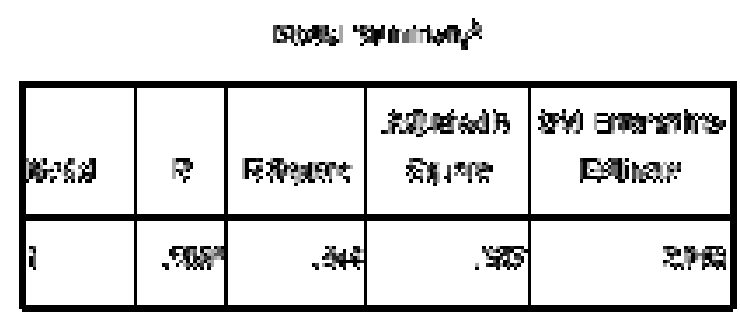

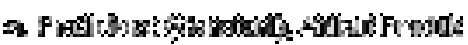

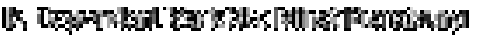

Berdasarkan hasil perhitungan pada tabel 4.9, diketahui bahwa nilai koefisien korelasi (R) dalam penelitian ini 0,586 yang berarti hubungan korelasi antara variabel atribut produk terhadap minat menabung adalah 0,586 atau 58,6\%. Adapun koefisien determinsi ( $R$ Square) mengukur seberapa jauh model menerangkan variasi dependen. Berdasarkan hasil olah data dari tampilan output SPSS Model Summary diperoleh nilai R Square sebesar 0,344. Nilai tersebut menunjukan besarnya pengaruh variabel atribut produk terhadap minat menabung. Hal ini berarti variasi perubahan variabel minat menabung (Y) dipengaruhi oleh perubahan variabel independen atribut produk (X) sebesar 34,4\%, sedangkan sisanya $(100 \%-34,4 \%=65,6 \%)$ dipengaruhi oleh faktor lain diluar penelitian ini.
Berdasarkan hasil perhitungan statistik, maka dapat diketahui bahwa variabel tentang atribut produk memiliki nilai t-hitung sebesar $7,129>$ nilai $t$-tabel sebesar 1,988, serta tingkat signifikannya lebih besar dari taraf kepercayaan sebesar $10 \%$ yaitu $0,000<0,05$. Dengan demikian nilai tersebut menunjukan bahwa variabel atribut produk (X) memberikan pengaruh yang signifikan terhadap variabel minat menabung (Y). Maka dari pembahasan ini menunjukan bahwa variabel atribut produk mempengaruhi minat menabung nasabah di BRI Syariah KC Palu Wolter Monginsidi.

Hasil penelitian ini didukung oleh penelitian sebelumnya yang dilakukan oleh Roni Andespa yang membuktikan bahwa variabel atribut produk memiliki pengaruh positif dan signifikan terhadap minat menabung nasabah di BRI Syariah, dari hasil nilai $\mathrm{R}^{2}$ pada model penelitian adalah sebesar 0,557 atau 55,7\%. Dalam penelitian Shofia Moizhotun Hasanah yang membuktikan bahwa atribut produk berpengaruh positif dan signifikan terhadap minat menabung.

Atribut produk adalah suatu komponen yang merupakan sifat-sifat 
produk yang menjamin agar produk tersebut dapat memenuhi kebutuhan dan keinginan yang ditetapkan oleh pembeli. ${ }^{26}$

Dengan adanya atribut yang melekat pada suatu produk yang digunakan konsumen untuk menilai dan mengukur kesesuaian karakteristik produk dengan kebutuhan dan keinginan. Bagi perusahaan dengan mengetahui atribut-atribut apa saja yang bisa mempengaruhi keputusan pembelian maka dapat ditentukan strategi untuk mengembangkan dan menyempurnakan produk agar lebih memuaskan konsumen. Kesimpulan bahwa variabel atribut produk mempengaruhi minat menabung nasabah di BRI Syariah KC Palu Wolter Monginsidi.

\section{KESIMPULAN}

Berdasarkan pembahasan penelitian yang telah dilakukan terkait dengan pengaruh atribut produk tabungan Faedah terhadap minat menabung nasabah di BRI Syariah KC Palu Wolter Monginsidi, maka dapat ditarik kesimpulan sebagai berikut :

Pengujian secara parsial pada variabel independen yaitu atribut produk terhadap variabel dependen yaitu minat menabung, maka hasilnya menunjukan bahwa variabel atribut produk berpengaruh secara parsial

\footnotetext{
${ }^{26}$ Kotler, Prinsip-Prinsip Pemasaran (Ed. XII, Jakarta: Erlangga, 1997),72.
}

memberikan pengaruh yang positif dan siginifikan terhadap minat menabung nasabah di BRI Syariah KC Palu Wolter Monginsidi. Artinya semakin tinggi kepercayaan nasabah terhadap atribut produk maka semakin tinggi pula minat nasabah dalam menabung menggunakan tabungan Faedah.

\section{Daftar Pustaka}

Antonio, Muhammad Syafi'i. Bank Syariah dari Teori ke Praktik. Cet. I. Jakarta: Gema Insani, 2001.

Arikunto, Suharsimi. Prosedur Penelitian (suatu pendekatan praktik). Jakarta: Rineka Cipta, 2010.

Bungin, M. Burhan. Metodologi Penelitian Kuantitatif. Jakarta: Prenada Kencana Group, 2005.

Chaplin, J.P. Kamus Lengkap Psikologi. Cet. XIV. Jakarta: Rajawali Pers, 2011.

Hamidi, M. Luthfi. Jejak Jejak Ekonomi Sya riah. Cet. I. Jakarta: Senayan Abadi P ublishing, 2003.

Hendy, Untung dan Edi, Wibowo. Mengapa Memilih Bank Syariah?. Cet. I. Bogor: Ghalia Indonesia, 2005.

Kasmir. Pemasaran Bank. Edisi revisi. Cet. III. Jakarta: Kencana Prenada Media Group, 2008.

Kotler. Manajemen Pemasaran. Edisi XII. Jakarta: Prenhallindo, 1997.

Madura, Jeff. Pengantar Bisnis Buku 1. Edisi IV. Jakarta: Salemba Empat, 2000.

Martono, Nanang. Metode Penelitian Kuantitatif Analisis Isi dan Analisis 
Data Sekunder. Edisi revisi II. Cet V. Jakarta: PT. RajaGrafindo Persada, 2016.

Mappiare, Andi. Psikologi Remaja. Surabaya: Usaha Nasional, 1997.

Moeliono, Anton M, dkk. Kamus Besar Bahasa Indonesia. Jakarta: Balai Pustaka, 1999.

Moleong, Lexy J. Metode Penelitian Kuantitatif. Edisi Revisi. Bandung: PT. Remaja Rosdakarya Off set, 2006.

Muhaimin. Korelasi Minat Belajar Pendidikan Jasmani terhadap hasil Belajar Pendidikan Jasmani. Semarang: IKIP, 1994.

Muhammad. Sistem dan Prosedur Operasional Bank Syariah. Edisi revisi. Yogyakarta: UII Press, 2008.

------. Metode Penelitian Ekonomi Islam Pendekatan Kuantitatif. Cet. I. Jakarta: Rajawali Pers, 2008.

Noor, Juliansyah. Metodologi Penelitian: Skripsi, Tesis, Disertasi, dan Karya Ilmiah. Cet. VI. Jakarta: KENCANA, 2016.

Nurdin, N., Pettalongi, S. S., \& Mangasing, M. (2019, 26-27 Sept. 2019). Understanding Digital Skill Use from The Technology Continuance Theory (TCT). Paper presented at the 2019 6th International Conference on Information Technology, Computer and Electrical Engineering (ICITACEE).

Poerwadarminta, WJS. Kamus Umum Bahasa Indonesia. Jakarta: Balai Pustaka, 1982.

Priyanto, Dwi. Analisis Korelasi, Regresi dan Multivariate dengan SPSS. Cet. I. Yogyakarta: GAVA MEDIA, 2013.
Rivai, Veitzhal. Islamic Marketing. Jakarta: Gramedia Pustaka Utama, 2012.

Santosa, Sri Hardjanti, dan Daromi S. Kebijakan Bauran Pemasaran. Yogyakarta: BPFE, 1992.

Shaleh, Abdul, Rahman, dkk. Psikologi Suatu Pengantar Dalam Perspektif Islam. Jakarta: Kencana, 2004.

------. Psikologi Suatu Pengantar (Dalam Perspektif Islam). Jakarta: Pernada Media, 2004.

Sudaryono. Metodologi Penelitian. Jakarta: Rajawali Pers, 2017.

Sugono, Dendy, dkk. Kamus Bahasa Indonesia. Edisi IV. Jakarta: Pusat Bahasa, 2008.

Sujarweni, V. Wiratna. SPSS Untuk Penelitian. Yogyakarta: Pustaka Baru Press, 2015.

Sukanto. Nafsiologi. Jakarta: Integritas Press, 1985.

Sulaiman, Wahid. Analisis Regresi Menggunakan SPSS: Contoh Kasus dan Pemecahannya. Yogyakarta: Andi, 2010.

Suryabrata, Sumardi. Metodologi Penelitian. Jakarta: PT. RajaGrafindo Persada, 2010.

Syofian, Siregar. Statistika Deskriptif untuk Penelitian. Ed. 1, Cet. 1. Jakarta: PT. RajaGrafindo Persada, 2010.

Tjiptono, Fandy. Strategi Pemasaran. Cet. I. Yogyakarta: Andi, 1997.

Umar, Husein. Riset Pemasaran \& Perilaku Konsumen. Jakarta: PT. Gramedia Pustaka Utama, 2000.

Winda, dan Haryadi, Sarjono. SPSS vs LISREL. Sebuah Pengantar Aplikasi Untuk Riset. Jakarta: Salemba Empat, 2011. 
Yayasan Penyelanggara Penerjemah Penafsir Al-Qur'an. Al-Qur'an Dan Terjemahnya. Jakarta: DEPAG, 1989.

https://www.brisyariah.co.id

Iqbal dalam Rahman El-Yunusi, "Pengaruh Atribut Islam, Komitmen Agama, Kualitas Jasa dan kepercayaan terhadap Kepuasan dan Loyalitas Nasabah Bank Syariah (pada Bank Muamalat Kota Ssemarang)", Jurnal Annual Converence On Islamic Studies ke 9 tahun, Dosen Prodi Ekonomi Islam Fakultas Syariah IAIN Walisongo Semarang, 2009.

Laporan Tahunan 2018 Annual Report, Menapak Esok dengan Digitalisasi.

Roni Andespa, "Pengaruh Atribut Produk Terhadap Minat Menabung Nasabah di Bank Syariah". Skripsi. Padang: U niversitas Islam Negeri Imam Bonjol Padang, 2018. http://journal.febi.uini b.ac.id. Di akses 28 Desember 2018.

Rahmawati, Siti "Pengaruh Tren Fashion terhadap Keputusan Membeli Busana Muslim dikalangan Mahasiswa Institut Agama Islam Negeri (IAIN) Palu". Skripsi tidak diterbitkan. Palu: Jurusan Ekonomi Islam Fakultas Syariah dan Ekonomi Islam IAIN Palu, 2017.

Shofia Mauizotun Hasanah, "Pengaruh Kuali tas Pelayanan, Pengetahuan Konsume $\mathrm{n}$, dan Periklanan Program Faedah Ta bungan BRI Syari'ah Terhadap Minat Menabung Nasabah". Skripsi Yogya karta : Program Studi Keuangan Isla m Fakultas Syari'ah Dan Hukum Uni versitas Islam Negeri Sunan Kalijaga Yogyakarta, 2014. http://digilib.uin.s uka.ac.id. Diakses 28 Desember 2018
Yogi Iskandar, "Pengaruh Kesesuaian Kompensasi terhadap Kinerja Karyawan pada PT. Bentoel Distribusi Utama Cabang Palu",(Skripsi), diakses 13 Juni 2019.

Zahratul Aini, "Pengaruh Produk-Produk Bank BRI Syari'ah Terhadap Minat Menabung Masyarakat Desa Aikmel Kecamatan Aikmel Kabupaten Lombok Timur". Skripsi. Mataram : Jurusan Ekonomi Syari'ah Fakultas Syari'ah Dan Ekonomi Islam Universitas Islam Negeri Mataram : 2017.

http://etheses.uinmataram.ac.id. Diakses 28 Desember 2018. 